\title{
The Pageant of History: Nostalgia, the Tudors, and the Community Play
}

\author{
Michael Dobson \\ Birkbeck, University of London
}

\begin{abstract}
This paper considers the persistence of the Renaissance pageant in modern and post-modern culture, both as a recurrent metaphor for history in general and as a feature of stage, cinematic and communal representations of early modern history in particular. After examining the status of public processions in Renaissance London as conscious revivals of the Roman triumph, indebted at the same time to aspects of the medieval mystery plays, the essay examines the English historical pageants of the Edwardian and inter-war years as themselves revivals of both Renaissance pageantry and aspects of the Shakespearean history play. It looks in particular at their emphasis on the Tudor monarchs and on the ethnic origins of Englishness, identifying the fading of the pageant as a genre in the post-war years with the collapse of certain ideas about English exceptionalism and historical continuity.
\end{abstract}

KEYWORDS: Pageants, processions, Edwardian outdoor theatre, amateur historical drama, Tudor monarchy in popular culture.

In thinking about the early modern past in general, Anglophones still habitually use the phrase "the pageant of history," as if picturing the sequence of historical events as so many decorated floats in a passing procession. The project of this essay is to unpack this dead metaphor, to think through the pageant of history in terms of the history of pageants. It will examine the extent to which the "pageant of history" metaphor hasn't in fact been dead at all over the last century, but lived on for film-makers determined to make an emblematic spectacle of the Renaissance, and for their immediate precursors in amateur dramatics, who re-enacted the early modern 
period on the village greens of England. The essay will proceed in three stages: first, it will outline the pre-history of the modern pageant, by looking at its forebears and analogues in the Renaissance proper; then it will look at how and why Renaissance history and drama were so central to the great pageants of the early twentieth century; and then it will consider how pageantry, and the assumptions about the nature of history which it encodes, migrated into cinematic depictions of the sixteenth century. The pageant finally disappeared after the Second World War, I hope to show, because it had always encoded a set of beliefs about the nature of British history which by the 1950s, for all the "New Elizabethan" rhetoric of Coronation Year, could no longer be sustained.

\section{Pageants before Pageants}

During the first half of the twentieth century, although these events have attracted little scholarly attention to date, ${ }^{1}$ English cathedral cities, market towns and hamlets put on a large number of historical pageants, habitually preoccupied with what the English think of as the Tudor period. Before we automatically dismiss these attempts at re-enacting the Renaissance as merely embarrassing and inaccurate distortions of the past, amateurishly staged in the service of local self-aggrandisement, it's worth reflecting on the extent to which the Renaissance itself was just such an inaccurate and selfaggrandising re-enactment in the first place.

Attempts by Renaissance antiquarians to reconstruct ancient Roman victory processions, as in the works of Italian humanists such as Flavio Biondo (in the 1450s) and Onofrio Panvinio (in the 1550s), overlapped with massive exercises in re-enacting them. In 1443, for example, Alfonso of Aragon staged a lavishly-researched parade through Naples to mark his accession to the city-state's throne the previous year, and similar events staged by the Gonzaga dynasty in Mantua informed their commissioning of a celebrated series of pictures, Mantegna's much-copied Triumphs of Caesar, in the 1480s. These processions, however, were comprehensively outdone by the Emperor Charles V's triumphal entry into Rome itself in 1536, in celebration of his allegedly Scipio-like military successes in North

\footnotetext{
${ }^{1}$ For the main exceptions, see Wallis (2006) and Esty (2003).
} 
Africa. In preparation for this occasion, Pope Paul III, to the disgust of Rabelais, had large swathes of the city demolished so as to clear what he believed were the processional routes favoured by Charles' pagan predecessors (Beard 2007:53-55). By the beginning of the seventeenth century, this drive to re-enact the processions of antiquity had even reached England, for example in the form of the moralized triumphal arches designed for James VI and I's coronation entry into London by, among others, that useful classicist and stagemanager Ben Jonson. For Renaissance princes, it appeared, history was cyclical: now redeemed and enhanced by Christianity, the golden ages of antiquity might be had all over again.

Off the streets, meanwhile, neoclassical processions had by now been part of the essential rhetorical grammar of the Renaissance for three centuries, largely thanks to the pan-European influence of Francesco Petrarch. Petrarch's Trionfi (c.1356-74) had established an enduring pattern by which an allegorical poem might rehearse an argument through recounting an imaginary victory parade. In England, Elizabeth I drew some the iconography of her own postmenopausal "second reign" from the Triumph of Chastity, and Petrarch's influence pervades Edmund Spenser's The Faerie Queene (1590-1596). Canto xii of book III ("Of Chastity"), features "The Maske of Cupid," in which no fewer than twenty-six successive stanzas describe the sorrows and delusions of romantic love in the form of a seemingly endless parade of allegorical floats, each introduced with the words "Next after him went...", "With him went...", "Next him was...", "After all these there marcht...", and so on.

Spenser calls this a "masque" rather than a pageant, and it is important both to the development of the pageant as a dramatic form in England and to its continuing resonances as a metaphor since that in Elizabethan times the word itself still carried connotations that were more Christian than classical. In current British usage the term "pageant" now generally refers to a dramatic genre. ${ }^{2}$ But a "pageant" was originally a thing rather than an event,

\footnotetext{
${ }^{2}$ Incidentally, and this is something to be careful of if you are ever doing picture research about pageants on the internet, in current North American popular usage a pageant is generally a beauty contest, in which the processions and floats display not civic worthies dressed up in a collective evocation of local history but nubile women in bathing costumes, exhibited competitively as if at an agricultural show. Even more
} 
namely the platform -whether static or taking the form of a wheeled wagon- on which a scene would be enacted in a medieval mystery play. At most, the term might extend to denoting a single episode from Biblical history played on one such structure. This original sense of the word survived the Reformation's abolition of the mystery cycles, though the technology that had hitherto been used for enacting the entire history of the world from the Creation to the Last Judgement was reassigned to less ambitious uses. Pageantwagons continued to rumble annually through the streets of London, now engaged, not in representing the fall and redemption of man, but merely in celebrating the city guilds' election of a new Lord Mayor.

The increasing elaboration of the Lord Mayor's Day procession during the reigns of Elizabeth and James brought in the city's first generation of professional playwrights. In 1585, for instance, George Peele published the speeches he had composed for the personnel manning the main allegorical cart deployed that year as The device of the pageant borne before Woolstone Dixi Lord Mayor of the City of London. Peele, significantly, when not scripting this sort of civic street theatre for the Mayor or designing flattering court performances for Elizabeth, was a pioneer of the chronicle play, the author of Edward I. In the hands of his Jacobean successors as scriptwriters to the city fathers, even the London mayoral pageant explicitly became a vehicle for secular history. Anthony Munday, for example, composed The Triumphs of Re-United Britannia for the procession of 1605, and from this period onwards the phrase "The Triumphs of..." becomes the standard title for this event, promoting the Lord Mayor to the status of an honorary Roman general. This particular pageant naturalizes the classical tradition by depicting the legendary founder of Britain, Aeneas' apocryphal son Brute, who divides the realm between his sons Locrine, Camber and Albanact to produce England, Wales and Scotland -the point to which the show tends is that these are now being gloriously reunited under King James. In processions such as this one, the Italianate revival of elements of the classical triumph, memories of the mysteries, and aspects of the native chronicle play were already beginning to combine to produce

of a snare for the unwary researcher, there is apparently also something in Guyana called the Ms Renaissance Pageant. 
something like the historical pageant as the twentieth century would come to know it.

Meanwhile history was also being dramatized in the purposebuilt playhouses, not least by William Shakespeare, who was working on his own script about the division of ancient Britain between three siblings, King Lear, around about the time that Munday's parade was grinding by. Given the importance of Shakespeare's histories to the subsequent development of the pageant, it's worth pausing to consider how Shakespeare himself understood the relations between pageantry and history.

Shakespeare's uses of the word "pageant" sometimes look like ours, and his history plays have been imitated and excerpted so extensively in the kinds of show which we would now call pageants that it is sometimes hard to remember that he hadn't seen one himself. In fact the one show-within-a-show in the canon that is usually referred to as a pageant -the Pageant of the Nine Worthies in the last act of Love's Labour's Lost- isn't properly categorized as such in Shakespeare's text at all, but with the prodigality of vocabulary for which this play is famous it is only called for, before either its form or its subject-matter have been chosen, as "some delightful ostentation, or show, or pageant, or antic, or firework" (5.1.105-107). If he missed out on the modern pageant, though, as a boy Shakespeare may have been among one of the last ever audiences for the old-style religious pageants of the Coventry mystery cycle. Perhaps this is why for Shakespeare the word "pageant" is usually tinged with a thoroughly medieval and melancholy contemptus mundi. "This wide and universal theatre," Duke Senior remarks in As You Like It in what sounds like an explicit glance back to the mysteries, "Presents more woeful pageants than the scene / Wherein we play in" (2.7.137-139). ${ }^{3}$ The word "pageant" for Shakespeare, as

\footnotetext{
${ }^{3}$ It's true that in Shakespeare the term sometimes functions, like "mockery," simply as a negative expression for any kind of representation, as when the Turkish fleet's feigned attack on Rhodes is described as a "a pageant" to keep the Venetians "in false gaze" (Othello 1.3.19-20). In a similar pejorative sense, Patroclus in Troilus and Cressida is said to "pageant" the Grecian commanders for the amusement of Achilles (1.3.151), and later on Thersites, an even more scurrilous impersonator, performs his satirical "pageant of Ajax" for the same audience (3.3.262-3). Simultaneously mocking and rueful, Troilus and Cressida, incidentally, contains three out of Shakespeare's total of sixteen uses of the word "pageant": appropriately for a play in which the Trojan army, beneath the gaze of Cressida and Pandarus, is reduced to a long classical procession of
} 
here, sometimes suggests the glories of this world revealed as a delusive show -as in Prospero's "insubstantial pageant faded," which leaves "not a rack behind" (The Tempest 4.1.155), or the doomed Antony's recollection of metamorphosing clouds at sunset as "black vesper's pageants" (Antony and Cleopatra 4.15.8). Alternatively, it sometimes denotes a show that is all about exposing and even punishing worldly vanities as such. Margaret in Richard III, for example, sees Queen Elizabeth in her short-lived prosperity as "The flattering index of a direful pageant, / One heaved a-high to be hurled down below" (4.4.85-86), while the Abbot of Westminster, moved by the edifying spectacle of Richard II's deposition, sighs that "A woeful pageant have we here beheld" (4.1.311). It's a sign of how unwary the ambitious Duchess of Gloucester is about the treacherous insecurity of earthly pomp in Henry VI part 2 that she announces her desire to make herself queen with the words "I will not be slack / To play my part in Fortune's pageant" (2 Henry VI 1.2.66-67). Whether interrupted by the "moved" Prospero or terminated by an abrupt fall from grace, pageants in Shakespeare don't have happy endings: the most elaborately-staged procession in the canon, complete with "shows, / Pageants, and sights of honour" (All is True [Henry VIII] 4.1.10-11), is for the coronation of the ill-fated Anne Boleyn.

Like the mystery cycles, then, for Shakespeare pageants expose human history as essentially insignificant, however gaudily ornamented. They are the inadequate and fleeting representations of a struggle for prizes that can't be kept and aren't worth having anyway, akin to the "little scene" with which Death temporarily indulges monarchs in the great "For God's sake let us sit upon the ground..." monologue in Richard II (3.2.160). It used to be argued that Shakespeare had simply secularized the optimistic teleological sweep of the mystery cycles, offering the providential story of the Wars of the Roses and the coming of the Tudors as a specifically English counterpart to the providential story of the Fall and its ultimately fortunate consequences. ${ }^{4}$ This now seems questionable,

sexual talent (1.2.177-240), the other comes when Troilus, who has clearly read Petrarch and Spenser, refers to "all Cupid's pageant" (3.2.71-2).

${ }^{4}$ Whether or not his history plays really offer the Tudor dynasty as the political equivalent of eternal salvation now seems more questionable -they might just as well be read, surely, as dramatizing English royal government as a problem as much as a 
but what Shakespeare's histories undoubtedly do when considered as a single connected sequence -as the Folio prints them- is to respond to the mystery plays' provision of a kind of drama which takes Mankind as its subject across the whole of cosmic history by producing instead a kind which takes the English monarchy as its subject across just a couple of centuries of national history. As such they provide one important precedent for the new form of chronicle play which would stage Shakespeare's England in the twentieth century.

\section{Pageants: The Golden Age}

Some traditions of Renaissance processional were kept alive down the succeeding years by the Lord Mayor's Day parade and all those Hanoverian coronations, but the rediscovery of early modern pageantry per se begins in earnest in the Romantic period. Just as early modern humanists had participated in the Renaissance by researching classical parades, so late eighteenth-century antiquarians did their bit for Romanticism by discovering and publishing every detail they could of Renaissance pageantry, now newly-cherished as the expression of a richer and more colourful lost world. Between 1788 and 1805 , for instance, John Nichols, a worthy English heir to Panvinio, published a massive three-volume compilation of all the surviving records he could find of The Progresses and Public Processions of Queen Elizabeth. This publication served as a major resource both for the designers of historical spectacle in the theatre, such as J.R. Planché, and for the authors of historical novels, such as Sir Walter Scott, whose Kenilworth (1821) draws heavily on Nichols throughout (Dobson and Watson 2002:111-115,139-140). The desire not just to research but to re-enact these Renaissance events finally achieved full expression in 1905, in the first outdoor work of a single remarkable artist, Louis Napoleon Parker.

Every bit as commanding as his Christian names might suggest, Parker had already followed three careers before inventing the Edwardian historical pageant. He was a respected composer, who had been made a fellow of the Royal Academy of Music in 1898, and,

solution, so many theatrical depictions of one long systemically incurable succession of succession crises. 
as well as taking an interest in the English folk-song revival associated with Cecil Sharp and Ralph Vaughan-Williams, he was one of the first and keenest English disciples of Wagner, whose grandiose notions of a total theatre embodying the consciousness of a people he clearly sought to emulate. Parker had also established himself as a successful West End playwright, enjoying a transatlantic hit, for example, with his costume drama The Cardinal (1903). Just as importantly to his subsequent career handling large and potentially mutinous crowds as a pageant-master, Parker had also spent nineteen years as a schoolteacher, at Sherborne School in Dorset. Sherborne was one of a number of private schools involved in the educational outdoor revival of Greek tragedy, a form which for Parker and other pageant-masters, as for Wagner, constituted an enabling precedent. ${ }^{5}$ It was in celebration of the $1200^{\text {th }}$ anniversary of its foundation that Parker devised his first historical pageant, staged among the ruins of the town's Norman castle in the summer of 1905 by a cast of some 900 local volunteers, with all the profits from its 2,00o ticket sales per show donated to local charities (Goodden 1905; Parker 1905).

This massive theatrical
spectacle attracted extensive
national press coverage, and it
immediately caught the public imagination. Parker was promptly commissioned to devise another such show in Warwick the following summer, this one employing a cast of 2,000 and seating 5,000 spectators per show (Parker 1906). His ensuing Dover pageant of 1908 was on a similar scale (Parker 1908). By the end of 1909 Parker had also produced pageants for Bury St Edmunds, Colchester, and York. Liverpool, Potter Heigham, Oxford and St Albans, among many smaller

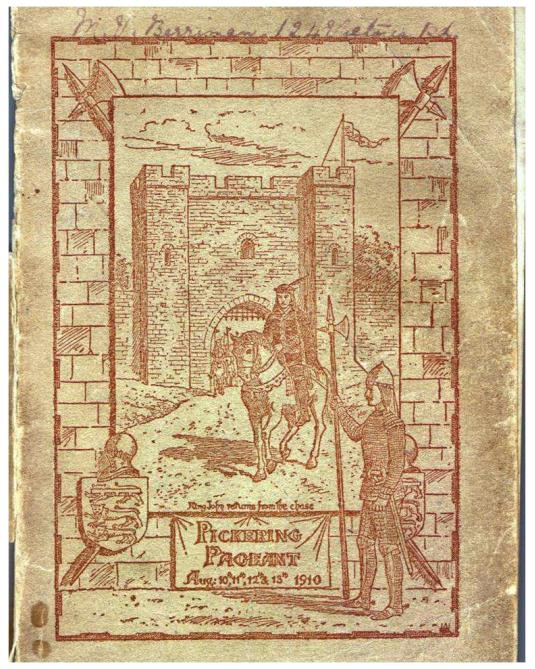

Figure 1. Cover of the Pickering Pageant script (Hudson 1910).

${ }^{5}$ On this movement and its influence on amateur Shakespearean performance see Dobson (2006). 
towns, staged their own in 1907; Chelsea, Cheltenham, Winchester and Pevensey theirs in 1908 (Withington 1918; Yoshino 2005; Ryan 2007). During the ensuing few years the vogue spread to ever further reaches of the kingdom. In the week of August $10^{\text {th }}-13^{\text {th }} 1910$, for instance, a pageant mainly scripted by one Gilbert Hudson was staged "in the historic ruins of Pickering Castle" in North Yorkshire, in what the published script-come-programme (fig. 1) makes clear was a concerted bid to attract more visitors to this little-known market town (fig. 2, fig. 3). Such

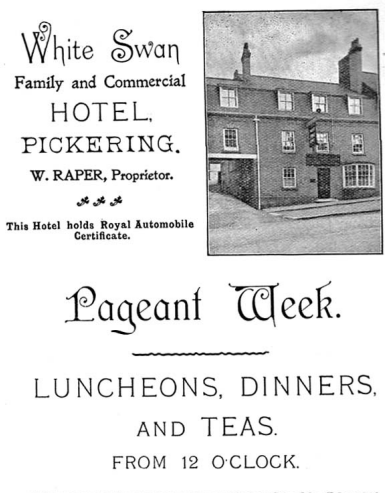

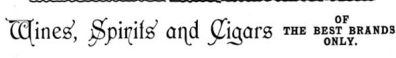

Carriages meet all Jrains

To convey Visitors to the Grounds at reasonable charges. pageants continued to be staged down to the outbreak of the Second World War: E.M. Forster scripted two, Abinger Pageant (1934) and England's Pleasant Land (1938), which would provide part of the inspiration for the Poyntz Hall pageant at the centre of Virginia Woolf's novel Between the Acts (1941) (Esty 2003:4654).

Figure 2. Advertisement for the special arrangements made by the White Swan hotel for the accommodation of those visiting Pickering to see the 1910 pageant (Hudson 1910).

Figure 3. Dr R.L. Kirk and other cast members driving about Yorkshire in Kirk's prize-winning Talbot car "Old Reliable" advertising the 1910 Pickering pageant. Kirk is the driver, in the medieval helmet.

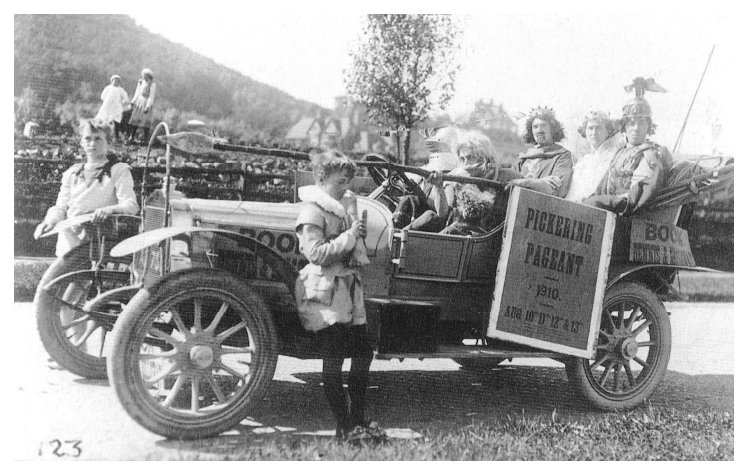

In essence, as Roger Simpson has observed, the pageant as created by Parker is "a chronicle play in which a social body rather than an individual is the hero" (Simpson 2008:63). As a genre, it extends the reach of the Shakespearean history play chronologically 
to something getting back towards that of the mysteries -the Warwick pageant covers 2,000 years instead of a mere 150- but it narrows that scope geographically, dealing not with Mankind or the English monarchy but with the development of a single local community. Despite its thirty-year heyday, the form didn't evolve much, partly because few individuals other than Parker, Frank Lascelles and Mary Kelly, author of How to Make a Pageant (1936), ${ }^{6}$ ever dared attempt more than one (Kelly 1934:737). ${ }^{7}$ But one other reason for the way in which the overwhelming majority of these shows follow exactly the recipe pioneered by Parker at Sherborne is simply that he got it right first time. As far as the Edwardian provinces were concerned, this sort of event presented the pageant of their history just as they wanted to see and understand it. Mary Kelly describes the usual pattern perfectly:

The majority of pageants resemble each other as closely as peas. There is the Spirit of the Ages dressed in grey-blue, or Father Time, or some character, who "narrates" (usually in rather halting blank verse) between the episodes, to explain what they are about. There are the Episodes: The Romans occupying Britain, The Founding of an Abbey, An Olde Englyshe Fayre, The Visit of Good Queen Bess ... and so on; ending with a great round-up of Spirits, of Peace, of Harmony, of the District Nursing Association, the Boy Scouts, the Women's Institutes, the British Legion, and a number of other associations, followed by all the performers, all singing "Land of Hope and Glory." (Kelly 1934:689)

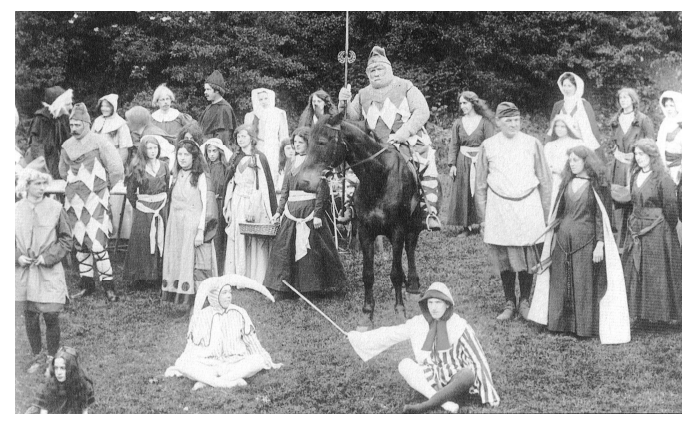

Figure 4 .

The Fair Scene, Pickering Pageant, 1910, starring Councillor Robert Dobson (mounted).

\footnotetext{
${ }^{6}$ This book is in fact merely a slightly expanded paraphrase of Kelly (1934).

${ }^{7}$ On Kelly, see especially Wallis (2006:102-8).

${ }^{8}$ The Fair Scene was a particular highlight of the Pickering pageant (Hudson 1910:2631, fig. 4), and was repeated by popular request at the Grand Pickering Gala on July $26^{\text {th }} 1911$.
} 
As Kelly's account suggests, the form of the pageant was by its very nature euphoric. The community that is any given pageant's subject is self-evidently alive and well at the end of the story and proudly re-enacting iconic episodes from its own history. In the pageant, the Shakespearean chronicle play's juxtaposition of tragic kings against comic people is simply transposed, to produce instead a juxtaposition of potentially tragic important visiting metropolitans, often monarchs, against mainly comic and perpetually enduring locals, both yeomanry and gentry. ${ }^{9}$ The pageant, though, could offer something that Shakespeare's histories could not -even when they were staged by $\mathrm{H}$. Beerbohm Tree with immense processions designed by Parker himself in return for loans of stage armour for his pageants. That was, to quote Parker's American disciple Percy Mackaye, "drama of and by the people, not merely for the people" (1916:xviii): the site-specific re-animation of the local past through collective amateur spectacle. That spectacle, with the bulk of the audience sheltered and immobilized in a temporary grandstand, inevitably consisted very largely of successive processions, characteristically seen approaching across long distances. If castle ruins weren't available as a backdrop, Mary Kelly recommended using wood-fringed spaces featuring reflective bodies of water, which might redouble the visual effect (fig. 5). She was particularly keen on employing horses, preferably ridden by expert members of the local hunt -Humans may fail to get the drama across, she observes, but horses never do (Kelly 1934:786,929). The re-enactment

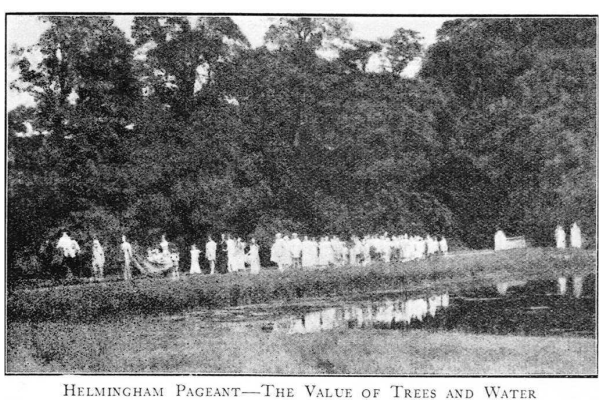
of the triumph, in short, was being re-enacted yet again.

Figure 5. Mary Kelly's illustration of an ideal pageant setting, drawn from one of her own projects. "Helmingham Pagean - The Value of Trees and Water"

Kelly (1934:736).

\footnotetext{
${ }^{9}$ For a case-study in the local politics of all this, see Woods (1999).
} 
As for what historical incidents these processions should dramatize, most pageant-masters shared a sense of the canon of recognizable English history which they had imbibed from a combination of Shakespeare, the Britannia section from Caesar's Gallic Wars, and the works of Sir Walter Scott. After their brief forays into prehistory, the Warwick and St Albans pageants, for example, included substantial excerpts from the Henry VI plays, about Warwick the Kingmaker and the battle of St Albans respectively, while the Dover pageant somehow found a pretext for incorporating parts of Henry $V$-Parker's Warwick pageant, incidentally, also incorporates the arraignment at Warwick of Piers Gaveston from Marlowe's Edward II, the only stage history which that controversial play would have for many years. The spirits of History and Imagination who compere the Pickering pageant, similarly, after giving us a bad king John straight out of Ivanhoe, depict Richard II confined in Pickering castle, where he quotes verbatim from Shakespeare's play about himself (in between, he is obliged to endure a local jester, and a choir of Yorkshire maidens who sing him "Sumer is icumen in") (Hudson 1910:39-44).

What is especially striking about most of these pageants is the prominence they give to the Tudor period, especially the reign of Elizabeth. Dover varies the pattern slightly by producing a youngish Henry VIII showing the harbour fortifications to Katherine of Aragon. But Warwick and St Albans both feature immense processional guest appearances by an Elizabeth and her court straight out of Kenilworth.

The last episode of the Sherborne pageant is set in 1593, when Sir Walter Raleigh comes home to his manor and has his tobaccopipe extinguished by an anxious servant, while Parker's 1907 pageant at Bury St Edmunds culminates with a recreation of Elizabeth I's visit in 1578. Likewise, although brave queen Bess couldn't appear in person at Pickering because everyone knew she had never risked travelling that far North, the final scene enacted there in 1910, as in several other Edwardian pageants, depicted news reaching the town of the defeat of the Spanish Armada in 1588. The last words of dialogue proper, before the choric spirits begin their concluding fourteeners and the assembled company sing "The Song of Pickering" and "O God our help in ages past," are "God save our gracious Queen Elizabeth!" -at which "Banners [are] displayed," 
there are "Trumpetings, shouts and cheers," and "Girls dance" (Hudson 1910:49). ${ }^{10}$ After the Elizabethans, apparently, unless your town was picturesquely involved in the Civil Wars as dramatized in Scott's Woodstock, all was anticlimactic, pageantry-free modernity, and hardly worth staging. ${ }^{11}$ As a result, almost all of Mary Kelly's specific advice on how to cast a pageant concerns how to get the right person for "the familiar Queen Elizabeth scene" (Kelly 1934:930,931). It's as if in lieu of having a formally-recognized national costume in which to dress up on special occasions, the English simply resort to farthingales and doublet and hose as an instinctive default setting.

When Parker himself cashed in on the success of his outdoor triumphs by composing a comparable show for ordinary commercial presentation, it was, predictably, another Tudor spectacular. Drake: A Pageant Play in Three Acts was produced by Beerbohm Tree at Her Majesty's in 1912, and was then successfully revived soon after the outbreak of the First World War. It finishes with one of Parker's signature huge processional crowd scenes, this one representing the victory parade to St Paul's after the repelling of the Armada:

[...] the People all turn towards the QUEEN and DRAKE with outstretched arms. CRIES: "God Save the Queen!" - "God Save Drake!" - "God Save England!" - Flags are waved. Roses are tossed on high, trumpets blare, bells clash, and the sun quivers on the QUEEN and DRAKE. (Parker 1912:67)

In a less exalted mood, E.F. Benson's fictitious pageant in Mapp and Lucia (1931) similarly centres entirely on Elizabeth and her favourite sea-dog. The comparatively unambitious Riseholme pageant depicted by Benson simply consists of Elizabeth knighting Drake on a replica of the Golden Hind specially built in the village pond -hence plenty of greenery and reflective water- and then, cued by a messenger announcing the approach of the Armada, processing across the road to make her 1588 Tilbury speech outside the local pub.

10 "The Song of Pickering" was published commercially by Novello and Sons of London, independently of the pageant's text, presumably in a further attempt to raise the profile of "Hill-guarded Pickering, / Queen of our Vale!" (Hudson 1910:55-6).

${ }^{11}$ More recent history could be left to Noel Coward, whose Cavalcade (1931), and This Happy Breed (1939) are essentially pageant-like chronicles of representative families instead of representative towns. 
Why this preoccupation with Elizabeth in the early twentiethcentury pageant? One local reason is that these shows, town-specific though they may be, partake extensively in contemporary enthusiasm for the British Empire (in the finale of the Warwick pageant, for instance, Britannia was attended by pages who each bore flags bearing the name of a British colony), an empire of which Gloriana was widely regarded as the founder. Kitty Barnes' 1931 pageant involving Elizabeth, Drake and Raleigh, for example, Adventurers, was specifically composed for performance by children on Empire Day (May 24), and even the inter-war armed forces shared this imperial enthusiasm for reliving the days of Elizabeth. Composers of pageants sometimes remarked that in both practicalities and aesthetics the form was closely analogous to the military tattoo (Kelly 1934:931), and the convergence is noticeable in both genres. At the culmination of the Sherborne pageant, for instance, in a striking anticipation of a subsequent quasi-military rally in another country, the entire cast, having assembled to the strains of Wagner's march from Tannhauser, all saluted in unison and shouted "Hail!"12 Similar effects characterized the "Pageants of Victory" staged in some towns to mark the conclusion of the First World War. Oxford's, incidentally, depicting each of the allied nations in turn, got right back to the roots of the pageant when it represented Italy by a re-staging of Petrarch's triumphal procession through Rome to be garlanded with laurels. It also enlisted the Bard, representing France, perhaps tactlessly, by a lavish re-enactment of the betrothal ceremony of Katharine de Valois and Henry V at Troyes using dialogue from the last scene of Shakespeare's play (de Bergerac 1919:25-27,21-23). ${ }^{13}$ This military enthusiasm for Henry $V$ lasted for some time: the Army's tattoo at Aldershot in 1930, for instance, incorporated an abbreviated pageant adaptation of the battle scenes, which to judge from surviving photographs looked remarkably like an anticipation of Laurence Olivier's 1944 film. This episode was followed by yet another grand processional pageant entry by Gloriana, this time impersonated by a soldier. At Aldershot she may have had the body of a weak and feeble woman, but she

\footnotetext{
${ }^{12}$ Given the widespread use of pageantry by subsequent totalitarian regimes of both right and left, it is worth considering whether the form Parker pioneered helped to encode and bequeath the megalomania inherent in high British imperialism.

${ }^{13}$ Petrarch, watched by Laura, recites one of his sonnets in Spenser's translation. This pageant also features the standard Elizabethan revels, here located at Banbury.
} 
had the heart and stomach of an officer and a gentleman. ${ }^{14}$ Despite the alarms and excursions of the First World War, apparently, in the 1930s Elizabeth's victory in 1588 still marked a convenient happy ending, the point after which there were to be no more defining wars for national survival.

As this reading may suggest, the pageant was committed to a view of the past if anything more providential than that of Shakespeare's histories. Sherborne, Warwick and even Pickering were clearly always destined to flourish, just as the island nation as a whole was set aside for victory and security. "It is best to end on a note of joy or hope," advised Kelly, since for her the pageant was committed to a post-Enlightenment faith in the inevitability of progress: the ultimate subject of any worthwhile pageant, she explained, was "the gradual growth of the human mind" (Kelly 1934:691-692) -hence the occasional adaptability of the pageant to progressive causes, as in the case of E.M. Forster's liberal environmentalism, or Cicely Hamilton's suffragette play A Pageant of Great Women, 1910. That faith in improvement and change, however, was always counterbalanced by a deeply conservative assertion of continuity. In practice the implicit argument of the English local pageant is that Pickering always has been Pickering and always will be, forever peopled by the same townsfolk whatever successive fancy dress costumes they may put on. Even the first, prehistoric episode in Gilbert Hudson's 1910 pageant, a sort of small-scale rape of the Sabine women wordlessly enacted between "uplanders" and "shore-dwellers" beside a body of water which had ceased to exist long before the town was founded, calls its location "Lake Pickering" (1919:3-4).

Mary Kelly, when not involved with pageants, devoted herself to the rediscovery, or reinvention, of an English tradition of indigenous folk drama, derived from the mummings and Whitsun pastorals fleetingly mentioned by Shakespeare. Her own sense of how pageants should best be cast was at times not just nativist but explicitly genetic. Arguing against the custom of giving major, royal roles to local aristocrats, for example, she suggests that "The best

\footnotetext{
${ }^{14}$ Photographs of this event are preserved in the National Army Museum library in Chelsea; see NAM 1990-07-31.
} 
place for the County is in the representation of its ancestors." ${ }^{15}$ Whatever the script may suggest about historical change, then, the performance of a historical pageant will give the impression that the same lord of the manor has always been the lord of the manor, even if over the centuries he has been something of a serial fashion-victim. To this extent the Edwardian pageant, like the medieval, suggests that human history is essentially trivial. It is full of gorgeous trappings, processing harmlessly past in sequence, but ultimately and perhaps consolingly- it alters nothing. Coronations may come and civil wars may go, but the replication of the same local families goes on forever.

Given this sense of genetic inheritance, it is appropriate that for Parker, Kelly and their colleagues the major pre-Tudor events not pre-digested by Shakespeare and Scott which a pageant might need to register were invasions. Needing an example of crowd dialogue, for instance, Kelly immediately reflects that "fugitives may cry the names of their pursuers, 'The Norsemen! The Norsemen! The Black Danes are coming!'" (Kelly 1934:736). (In this respect as in others these pageants also resemble Rudyard Kipling's popular children's book Puck of Pook's Hill, 1906, in which the spirit-master-ofceremonies who shows two children episodes of local history involving their nation's ancestors is Shakespeare's Puck himself). To the makers and consumers of English pageants, apparently, history consisted largely of the Romans sailing across, interbreeding and taking over, then the Saxons sailing across, interbreeding and taking over, then the Vikings sailing across, interbreeding and taking over, then the Normans sailing across, interbreeding and taking over, and then the Spanish Armada sailing across and not even managing to land. After which history was over, since German threat or no German threat there were to be no further changes to the ethnic identity of the English shires.

\section{Pageant into Cinema}

Change came in the Edwardian period, even so, including the development of new communications technologies. From the outset,

\footnotetext{
15 "[...] they can wear lovely clothes, and heraldry, and so on, and feel themselves as important as the principals" (Kelly 1934:930).
} 
pageants provided an irresistible subject for the owners of cine cameras, and footage survives from a number of these events (notably Warwick), albeit rather inaccessibly in local history archives. With the coming of sound cinema in the 1930s, though, film could suddenly deliver spectacle, dialogue and music to larger audiences even than those which came to Warwick or Dover. The new medium, however, did not immediately wipe out the pageant: it was merely that the pre-war talkies cannily adopted elements of the historical pageant as part of their stock-in-trade. The first internationally successful British sound film was that swaggering pageant Alexander Korda's The Private Life of Henry the Eighth (1933), and in 1937 Korda went on to produce Fire over England. Adapted from A.E.W. Mason's novel, this film, like any self-respecting pageant, reaches its climax with Elizabeth's visit to Tilbury in $1588-$ a sequence which begins with a long equestrian processional entry past woods and water of which Mary Kelly would have been proud. The link between the early costume movie and the pageant is even more obvious in another of this film's forbears, made two years earlier. Arthur B. Woods' Drake of England (1935) was simply a film adaptation of Louis Napoleon Parker's very own Drake. Sadly, it is now almost impossible to obtain Drake of England outside the archives of the British Film Institute. However, a less elusive direct successor goes one better than Parker, by not just providing the knighting, the Tilbury oration and the victory celebrations, but by compressing all three into one culminating crowd scene. In 1940, Michael Curtiz made The Sea Hawk, with Errol Flynn as the fictitious Geoffrey Thorpe and Flora Robson again playing Elizabeth. Thorpe is rewarded by the Queen for intercepting Spanish intelligence and warning of the approach of the Armada, in a finale of pure pageantry which neatly conflates the knighting of Drake, a topical paraphrase of the Tilbury speech, and the flag-waving and cheering of the Armada victory.

In Errol Flynn's other Elizabethan costume drama, however, the attitude to pageantry is very different, largely because the spectacle is designed for the consumption of a different national audience. Although Mary Kelly had advised canny business managers that "The interest in pageants is particularly great in America, and it is well worth advertising in the American shipping lines" (Kelly 1934:1035), in practice catering to an American perspective on the English past might prove fatal to most of the form's founding 
assumptions. While in 1905 the inhabitants of Sherborn, Massachusetts had sent a letter to Sherborne, Dorset, boasting of their "filial pride" in the "mother town" (Goodden 1905:15-17,27-28), Americans now increasingly saw their history not as a continuation of England's but as marking a complete ideological break from it: for them, established modernity now began not in 1588 but in 1776 . The early Technicolor spectacular The Private Lives of Elizabeth and Essex (1939), admittedly, begins in pure Parker mode, with a long Renaissance procession which is explicitly a triumph, and according to one spectator a Triumph of Love at that, as Essex parades through London after his victory at Cadiz eager to be reunited with his queen. But despite this public opening, this film's Elizabeth, unlike Flora Robson's, is strictly an indoor person, always shown in court settings within which the macho, outdoor Essex feels increasingly confined. She is never granted any such antique tickertape parade as his, and ultimately the film disowns Elizabeth, English history and pageantry alike. Essex grows out of all that pomp, yearning for a sincere man-to-man republic elsewhere, and in the end he chooses to accept execution quietly and off-screen rather than tolerate his subjection to an overdressed royal mistress any longer. In Hollywood costume drama like this, it isn't the crowd that represents us but the juvenile leads (here Essex and the young Penelope Rich, but not Elizabeth), who are usually as incongruously ahead of their time as a Connecticut Yankee at King Arthur's court. Much the same point is made in Bette Davis's second Tudor film, The Virgin Queen (1955). The film uses one canonical episode of courtly processional favoured by several pageants (the anecdote of Raleigh laying down his cloak for his queen in a puddle), but its perspective is ultimately anti-court, on the side of a Raleigh whose disregard for his cloak is based not on supreme courtiership but on the contempt for archaic frippery proper to a proto-American man of action. At the end of the film, Raleigh too leaves Elizabeth, sailing off to found Virginia with Joan Collins. ${ }^{16}$

In the post-war period, as this Hollywood film suggests, the triumph really belonged to American modernity rather than to English history, and in Europe too approaches to the early modern past were changing. The definitive public events designed to assert a continuity with the Renaissance were now not nationalistic

${ }^{16}$ On these films, see Dobson and Watson (2002:275-82). 
processions but international arts festivals, often centred on the revival of Shakespeare: the festivals at Edinburgh, Avignon, Verona, and so on were all founded in the 1950s, and several of them, as Dennis Kennedy has pointed out, were inaugurated with grand ceremonial productions of Richard II (Kennedy 2003). Similarly, the scholarly recovery of early modern court occasions, which underwent another periodic renaissance of its own from the 1960s onwards in the work of Stephen Orgel and others, now concentrated less on the militant processions of Queen Elizabeth than on the court masques of her pacific successor, James I. In England during the post-war "New Elizabethan" period, it was the festivals of the Renaissance rather than its triumphs which were to be revived, whether as cod "Renaissance Fayres" for the masses, as May Day celebrations for schoolchildren, or as more arcane shows for the elite. When Princess Elizabeth and her sailor husband Prince Philip visited Oxford in 1948, for instance, they were entertained not with a pageant about the victories of Drake but with a pastiche of an Elizabethan court entertainment, the rather strenuously optimistic Masque of Hope (Dobson and Watson 2002:76-8,231). The military tattoo aspect of the historical pageant now survived mainly among specialist clubs dedicated to re-enacting battles, such as the Sealed Knot. A few pageants were still staged in small villages, particularly around the time of the Festival of Britain, including one at Naphill in Buckinghamshire, but it was hard for them to muster the sort of budgets enjoyed by Parker in the glory days: this one was unable to afford more than Elizabeth's court and St George and the Dragon. ${ }^{17}$

But after the Blitz, in any case, as Woolf had already recognized in Between the Acts, it seemed much harder for the English to go on thinking of history as a providential fancy dress procession that was all about them but which they could simply sit back and savour as it passed by. As the Empire visibly imploded, moreover, it became impossible to celebrate its inevitable long-term triumph, and in the decade that saw race riots in Notting Hill, the days of a form that had believed that the Tudors had permanently indemnified not just the English Channel but the English gene-pool were clearly numbered. Despite its medieval Christian phase as an exposé of

17 See http://apps.buckscc.gov.uk/modes/projects/SWOPimage/RHW5061o.jpg; http://apps.buckscc.gov.uk/modes/projects/SWOPimage/RHW50614.jpg. On the later phases of the pageant-play, see especially Esty (2003). 
worldliness, as I've shown, the pageant as a dramatic form had remained faithful to its classical roots in the celebration of imperial triumph all along, and that triumph had now, in the best classical tradition, migrated westwards. For the post-war British, history was no longer a pageant -except, perhaps, in the sense in which Shakespeare had used the word all along. As Puck had put it: "Shall we their fond pageant see? / Lord, what fools these mortals be!" ( $A$ Midsummer Night's Dream 3.2.114-115).

\section{References}

Beard, Mary 2007. The Roman Triumph. Cambridge, MA: Harvard University Press.

De Bergerac, Bernice 1919. The Oxford Pageant of Victory, 1919. Oxford: Vincent Works.

Dobson, Michael 2006. "Shakespeare exposed: outdoor performance and ideology, 1880-1940." Ed. Peter Holland. Shakespeare, Memory and Performance. Cambridge: Cambridge University Press: 256-280.

Dobson, Michael, and Nicola Watson 2002. England's Elizabeth: An Afterlife in Fame and Fantasy. Oxford: Oxford University Press.

Esty, Jed 2003. A Shrinking Island: Modernism and National Culture in England. Princeton, NJ: Princeton University Press.

Goodden, Cecil B. 1905. The Story of the Sherborne Pageant. Sherborne: Bennett.

Hudson, Gilbert 1910. The Pickering Pageant. Pickering: Boak and Sons.

Kelly, Mary 1934. "Pageants." Ed. Harold C. Downs. The Theatre and Stage. 2 vols. London: Pitman. II: 689-692, 735-738, 783-786, 833-836, 881-884, 929932, 981-984, 1035-1038.

Kennedy, Dennis 2003. "Shakespeare and the Cold War." Eds. Angel-Luis Pujante and Ton Hoenselaars. Four Hundred Years of Shakespeare in Europe. Newark: University of Delaware Press: 163-179.

Mackaye, Percy 1916. Caliban By the Yellow Sands. New York: Doubleday.

Parker, Louis Napoleon 1905. The Sherborne Pageant. Sherborne: Bennett.

Parker, Louis Napoleon 1906. The Warwick Pageant. Warwick: Evans and Co.

Parker, Louis Napoleon 1908. The Dover Pageant. Dover: Grigg and Sons.

Parker, Louis Napoleon 1912. Drake. A Pageant Play in Three Acts. London: John Lane. 
(9)ederi 20 (2010)

Ryan, Deborah Sugg 2007. "'Pageantitis': Frank Lascelles' Oxford Historical Pageant, Visual Spectacle, and Popular Memory." Visual Culture in Britain 8/2: 63-82.

Simpson, Roger 2008. "Arthurian Pageants in Twentieth-Century Britain." Arthuriana 18/1: 63-88.

Wallis, Mick 2006. "Drama in the villages: three pioneers." Eds. Paul Brassley, Jeremy Burchardt and Lynne Thompson. The English Countryside Between the Wars: Regeneration or Decline?. Woodbridge: Boydell and Brewer: 102-115.

Withington, Robert 1918. English Pageantry: An Historical Outline. 2 vols. Cambridge, MA: Harvard University Press.

Woods, Michael 1999. "Performing Power: local politics and the Taunton pageant of 1928." Journal of Historical Geography 25/1: 57-74.

Yoshino, Ayako 2005. The Edwardian historical pageant. Cambridge Ph.D.

\section{Sources for the illustrations}

1. The cover of the Pickering Pageant script (Hudson 1910), formerly owned by M.V.Berriman (Writers' Resources, Oxford).

2. Advertisement for the special arrangements made by the White Swan hotel, from Hudson 1910 (Writers' Resources, Oxford).

3. Dr R.L. Kirk and other cast members driving about Yorkshire. Beck Isle Museum, Pickering, courtesy of Gordon Clitheroe.

4. The Fair Scene, Pickering Pageant, 1910. Beck Isle Museum, Pickering, courtesy of Gordon Clitheroe.

5. Mary Kelly's illustration of an ideal pageant setting. Kelly (1934:736) (Writers' Resources, Oxford).

How to cite this article:

Dobson, Michael. "The Pageant of History: Nostalgia, the Tudors, and the

Community Play." SEDERI 20 (2010): 5-25.

Author's contact: m.dobson@english.bbk.ac.uk

Submission: 03/08/2009_Acceptance: 26/12/2009 